Korean Chem. Eng. Res., 51(4), 426-431 (2013)

http://dx.doi.org/10.9713/kcer.2013.51.4.426

\title{
나노크기 $\mathrm{TiO}_{2}$ 의 제조에 미치는 첨가제 영향
}

\author{
김석현 · 나석은 · 김시영* · 김성수** · 주창식 ${ }^{\dagger}$ \\ 부경대학교 화학공학과 \\ 608-739 부산시 남구 용당동 산 100 \\ *부경대학교 기계시스템공학과 \\ 608-739 부산시 남구 용당동 산 100 \\ **부산 가톨릭대학교 환경행정학과 \\ 609-757 부산시 금정구 부곡3동 9 \\ (2013년 4월 16일 접수, 2013년 6월 15일 채택)
}

\section{The Effect of Additives on the Preparation of Nanosized $\mathrm{TiO}_{2}$ Particles}

\author{
Seok-Hyeon Kim, Seok-En Na, Si-Young Kim*, Seong-Soo Kim** and Chang-Sik Ju ${ }^{\dagger}$ \\ Department of Chemical Engineering, Pukyoung National University, San 100 Yongdang-dong, Nam-gu, Busan 608-739, Korea \\ *Department of Mechanical System Engineering, Pukyoung National University, San 100 Yongdang-dong, Nam-gu, Busan 608-739, Korea \\ **Department of Environmental Administration, Catholic University of Busan, 9 Boogok-3dong, Geumjeong-gu, Busan 609-757, Korea \\ (Received 16 April 2013; accepted 15 June 2013)
}

\begin{abstract}
요 약
비교적 낮은 온도와 상압에서 전구체 Titanium(IV) sulfate와 염기성 용액을 반응시키는 수열합성법을 이용하여 소 성과정을 거치지 않고 $\mathrm{TiO}_{2}$ 나노입자를 제조하였다. 염기성 용액의 종류 $\left(\mathrm{NaOH}, \mathrm{NH}_{4} \mathrm{OH}\right.$, Monoethanolamine, Diethanolamine, Triethanolamine), 첨가되는 계면활성제의 종류(CTAB, Span 20, SDBS)와 농도, 제조 온도, $\mathrm{pH}$ 등을 변화시켜 $\mathrm{TiO}_{2}$ 를 제조하였고, 생성되는 입자의 결정성, 입자크기 등과 같은 물리적 특성은 $\mathrm{XRD}, \mathrm{SEM}$, Zeta-potential 등을 사용하여 분석하였다. 또한, 광촉매적 특성을 확인하기 위하여 DRS를 통해 흡광면적을 측정, 비교하였다. 침전제 로 사용된 염기성 물질 중 $\mathrm{NaOH}$ 가 결정성이 우수하고 입자크기가 작은 $\mathrm{TiO}_{2}$ 를 제조하는데 가장 효과적임을 확인할 수 있었다. 계면활성제는 양이온성 계면활성제인 $\mathrm{CTAB}$ 를 첨가한 경우 다른 계면활성제보다 작은 크기의 $\mathrm{TiO}_{2}$ 를 제 조할 수 있었다. 그리고 동일한 조건에서 전구체인 $\mathrm{Ti}\left(\mathrm{SO}_{4}\right)_{2}$ 와 $\mathrm{CTAB}$ 의 농도비를 10 : 1로 조절한 경우 $\mathrm{CTAB}$ 를 첨가 하지 않은 경우보다 제조되는 $\mathrm{TiO}_{2}$ 입자의 크기는 약 $1 / 10$ 인 $5.8 \mathrm{~nm}$ 로 감소하였다.
\end{abstract}

\begin{abstract}
Nanosized $\mathrm{TiO}_{2}$ particles were prepared from titanium (IV) sulfate solution using base solutions at low reaction temperature $\left(95^{\circ} \mathrm{C}\right)$ and atmospheric pressure by hydrothermal precipitation method without calcination. The effects of preparation conditions, such as kind of base solutions $\left(\mathrm{NaOH}, \mathrm{NH}_{4} \mathrm{OH}\right.$, Monoethanolamine, Diethanolamine, Triethanolamine) and surfactants (CTAB, Span 20, SDBS), concentration of surfactants, temperature and $\mathrm{pH}$, on the physical properties of $\mathrm{TiO}_{2}$ particles have been investigated by XRD, SEM and Zeta-potential meter. Absorption area was also investigated by DRS in order to confirm the photocatalytic activity of the nanosized $\mathrm{TiO}_{2}$ particles. It was turned out that, among base solutions, $\mathrm{NaOH}$ provides the smallest $\mathrm{TiO}_{2}$ particles with excellent crystallinity. And cationic surfactant $(\mathrm{CTAB})$ prepared smaller $\mathrm{TiO}_{2}$ particles than any other surfactants. When CTAB is added in the concentration ratio of $\mathrm{Ti}\left(\mathrm{SO}_{4}\right)_{2}: \mathrm{CTAB}=10: 1, \mathrm{TiO}_{2}$ particles with particle diameter of $5.8 \mathrm{~nm}$ were prepared. This is approximately $1 / 10$ of that prepared without CTAB.
\end{abstract}

Key wards: Nanosized, $\mathrm{TiO}_{2}$, Surfactant, Hydrothermal Method, Photocatalyst

\section{1. 서 론}

$\mathrm{TiO}_{2}$ 는 광촉매로서 높은 화학 및 물리적 안정성, 광부식에 대한 저 항력, 무독성, 저렴한 가격을 가지고 있을 뿐만 아니라 $400 \mathrm{~nm}$ 이하 의 광원 조사에 의해 형성된 $\mathrm{TiO}_{2}$ 의 전자 대 정공의 산화력이 대단

\footnotetext{
${ }^{\dagger}$ To whom correspondence should be addressed.

E-mail: csju@pknu.ac.kr
}

히 높기 때문에 반영구적으로 사용할 수 있어 현재 공업적으로 페인 트나 화장품의 백색 안료, 센서, 배터리, 촉매분야, 태양전지나 물과 공기 중의 유기오염물질의 광분해와 항균, 방오 및 방취 등 광범위 하게 사용되고 있다[1-5].

광촉매 반응속도는 제조과정에서 제조조건에 따라 조절할 수 있 다. 예를 들어, 광촉매 반응은 일정한 파장의 빛 흡수, 광촉매 표면 에서의 전자와 정공 이동 및 재결합(electron-hole recombi nation) 
과 같은 3 가지 과정을 거쳐서 일어나게 되므로 광촉매의 입자구조 와 입자크기는 광촉매 반응속도에 큰 영향을 끼친다[6,7]. 특히, 나 노크기의 $\mathrm{TiO}_{2}$ 입자는 마이크론크기의 $\mathrm{TiO}_{2}$ 보다 넓은 비표면적을 가지고 있어 흡수하는 빛의 파장 범위가 확장되고 표면에 전자 및 정공 밀도가 증가하여 표면재결합이 주로 발생되면서 광촉매 활성 이 증가되고 제조조건에 따라 서로 다른 성질이 나타나게 된다[8$10]$.

나노입자 $\mathrm{TiO}_{2}$ 제조방법으로는 물리적 방법과 화학적 방법으로 구 분된다. 물리적 방법으로는 분쇄, 용매 증발법 등과 같은 물리적 성 질을 이용하는 방법이고 화학적 방법은 Sol-gel법, microemulsion법, 수열합성법, 기상법, solventhemal법, 침전제적하법, 고분자 첨가법 등과 같은 화학반응을 이용하는 방법이다.

Sol-gel법은 전구체로 금속 알콕사이드를 사용하는 경우 상온에서 가수분해반응에 의해 $\mathrm{TiO}_{2}$ 를 쉽게 제조 가능하고 수산화기를 제외 한 불순물이 혼입될 우려가 없어 고순도의 생성물을 제조할 수 있다 는 장점을 가지고 있지만 고온 소성과정이 필요하고 입자크기 조절 이 어렵다는 단점을 가지고 있다. 수열합성법은 비정질 형태의 티타 늄 수화물 또는 액상 상태의 티타늄 전구체를 고온, 고압에서 가열 하여 $\mathrm{TiO}_{2}$ 를 제조하는 방법으로 sol-gel법보다는 낮은 온도로 열처리 하여 열처리 동안 입자의 응집이 없어 일정한 결정상을 얻을 수 있 다는 장점을 가지고 있다. 하지만 수열합성법 역시 입자크기 조절이 어렵다는 단점을 가지고 있다[11]. 이러한 단점을 보완하기 위해 많 은 제조방법이 연구되는데, 특히 계면활성제를 이용하여 결정 크기 나 모양, 크기분포 등을 조절하는 연구가 최근에 활발히 연구되고 있 다 $[1,2,6,8,10]$. Chen 등 [6]과 Liao와 Liao [10]의 연구에서는 계면활 성제를 이용하여 $\mathrm{TiO}_{2}$ 의 크기나 모양을 조절할 수 있고 이를 이용하 여 활성 능력도 변화시킬 수 있다고 보고하였다.

본 연구에서는 전구체인 titanium(IV) sulfate( $\left.\mathrm{Ti}\left(\mathrm{SO}_{4}\right)_{2}\right)$ 수용액에 계면활성제를 첨가한 후, 비교적 낮은 온도에서 염기성 용액을 일정 한 속도로 적하하는 방법으로 결정성 입자들을 생성시켰다. 생성된 입자들을 여과한 후 $80{ }^{\circ} \mathrm{C}$ 에서 건조시킴으로써, 소성과정이 없는 한 단계의 수열합성법으로 나노크기의 $\mathrm{TiO}_{2}$ 분말을 제조할 수 있었다. 나노크기의 $\mathrm{TiO}_{2}$ 제조과정에서 염기성용액과 계면활성제의 종류, 반 응온도, 혼합 용액의 $\mathrm{pH}$ 등이 생성되는 나노크기 $\mathrm{TiO}_{2}$ 입자의 결정 화도, 입자크기 및 모양, 광학 특성 등에 미치는 영향에 대한 실험적 연구를 수행하였다.

\section{2. 실 험}

나노입자 $\mathrm{TiO}_{2}$ 전구물질로 $\mathrm{Ti}\left(\mathrm{SO}_{4}\right)_{2}$ 수용액(Kanto chemical co. lnc., Japan)을 사용하였고 침전제로 Monoethanolamine(MEA, Kanto Chemical co. Inc., Japan), Diethanolamine(DEA, Merck Schuchardt OHG Germany), Triethanolamine(TEA, Junsei, Japan), $\mathrm{NH}_{4} \mathrm{OH}$ (Junsei, Japan), $\mathrm{NaOH}$ (Sam-chun Chemicals, Korea)을 사용하였다. 계면활성 제는 Sodium dodecylbenzenesulfonate(SDBS, Sigma Aldrich, France), Span 20(Sigma Aldrich, USA), Hexadecytrimethyl ammonium bromide (CTAB, Sigma Aldrich, India)을 사용하였고 사용한 물은 탈이온화 된 증류수를 사용하여 수열합성법에 의해 나노입자 $\mathrm{TiO}_{2}$ 를 합성하 였다.

나노입자 $\mathrm{TiO}_{2}$ 합성에 사용한 합성장치와 실험방법은 $\mathrm{Na}$ 등 [12]과 같은 장치와 방법으로 합성하였고 합성된 침전물은 진공여과장치를
이용하여 $0.1 \mu \mathrm{m}$ 크기의 막여과지로 여과한 후 에탄올과 증류수를 이용하여 불순물이 나오지 않을 때까지 세척하였다. 이렇게 합성된 침전물을 진공건조기에서 $80{ }^{\circ} \mathrm{C}$ 에서 24 시간 건조하여 나노입자 $\mathrm{TiO}_{2}$ 를 각각 제조하였다.

한편 $\mathrm{TiO}_{2}$ 의 수열합성법에 의한 제조는 전구체인 $\mathrm{Ti}\left(\mathrm{SO}_{4}\right)_{2}$ 수용액 농도를 $0.5 \mathrm{M}$, 반응온도 $95{ }^{\circ} \mathrm{C}$ 로 고정된 반응조건 하에서 침전제를 $\mathrm{MEA}, \mathrm{DEA}, \mathrm{TEA}, \mathrm{NaOH}$, 암모니아수로 변화시켜 $\mathrm{TiO}_{2}$ 분말을 제 조하여 침전제 종류에 따른 제조특성을 확인하였다. 상기의 반응조 건과 동일한 반응조건 하에서 전구체와 일정 농도비의 계면활성제 (SDBS, Span 20, CTAB)를 변화시키면서 첨가한 후 침전제로 $\mathrm{NaOH}$ 를 사용하여 나노입자 $\mathrm{TiO}_{2}$ 분말을 제조하여 계면활성제 종류에 따른 제조특성을 확인하였다. 그리고 계면활성제를 첨가하여 $\mathrm{TiO}_{2}$ 분말 제조 시 전구체와 $\mathrm{CTAB}$ 의 농도비, 반응온도, 혼합용액의 $\mathrm{pH}$ 를 변 화시켜 $\mathrm{TiO}_{2}$ 분말을 제조하였고 각각 반응조건 변화에 따른 제조특 성을 확인하였다.

제조된 시료들의 결정성과 정성분석을 위해서 $\mathrm{X}$ 선 회절기(XRD, Rigaku D/MAX 2500, Japan)를 이용하였다. 각각 시료의 표면 상태 이미지와 결정형상은 SEM(Hitachi S-2400, Japan)을 사용하여 관찰 하였고, 흡광도 및 광촉매 활성을 알아보기 위해 UV-VIS Diffuse Reflectance Spectroscopy(DRS, Varian Cray 100, USA) 분석을 실시 하였고, Zeta-potential(Brookhaven instruments corporation, USA)을 사용하여 제조된 시료의 평균입자크기를 측정하였다.

\section{3. 결과 및 고찰}

\section{3-1. $\mathrm{TiO}_{2}$ 입자의 제조}

3-1-1. 침전제 및 계면활성제 종류가 $\mathrm{TiO}_{2}$ 입자의 결정성과 크기 및 형상에 미치는 영향

Fig. 1은 전구체인 $\mathrm{Ti}\left(\mathrm{SO}_{4}\right)_{2}$ 의 농도와 $\mathrm{pH}$ 를 각각 $0.5 \mathrm{M}, \mathrm{pH} 11.0$ 으로 일정하게 유지하면서 침전제인 염기성 용액의 종류를 변화시 켜 제조한 $\mathrm{TiO}_{2}$ 의 XRD 결과(a)와 동일한 제조조건에서 첨가되는 계면활성제를 변화시켜 제조한 $\mathrm{TiO}_{2}$ 의 XRD 분석결과(b)를 나타 내었으며, 제조된 $\mathrm{TiO}_{2}$ 입자는 회절각 $2 \theta=25.38(101), 38.14(004)$, 48.04(200), 55.02(105)에 peak를 나타내는 전형적인 anatase 구조 를 가진 것을 확인할 수 있다. Woo와 $\mathrm{Kim}[13]$ 과 $\mathrm{Kim}[14]$ 은 $\mathrm{TiO}_{2}$ 침전체를 구성하는 일차입자 모양이 $\mathrm{SO}_{4}{ }^{2}$ 와 같은 음이온의 영향 으로 침상에서 구상으로 변화함에 따라 침전되는 일차입자들 사이 의 모세관 힘을 약화시키게 되고 그 약화된 힘으로 인해 rutile 상 을 형성시키는 대신 anatase 상의 결정구조 형성을 가능하게 한다 고 보고하였다. 반면 Lee 등 [4]의 연구에서는 전구체로 $\mathrm{TiCl}_{4}$ 를 사용하여 $\mathrm{TiO}_{2}$ 를 제조하였는데 반응온도에 따라 rutile 상이 형성 되기도 한다고 보고하였다.

본 연구에서 제조된 $\mathrm{TiO}_{2}$ 의 XRD 결과 역시 $\mathrm{Woo}$ 와 $\mathrm{Kim}[13]$ 과 $\mathrm{Kim}[14]$ 의 연구와 같이 $\mathrm{SO}_{4}{ }^{2-}$ 의 영향으로 인해 anatase 결정구조의 $\mathrm{TiO}_{2}$ 입자가 제조되었다고 판단된다.

Fig. 1(a)를 보면 침전제로 $\mathrm{NaOH}$ 와 $\mathrm{NH}_{4} \mathrm{OH}$ 를 사용한 경우 MEA, $\mathrm{DEA}, \mathrm{TEA}$ 를 사용한 경우보다 결정성이 더 우수한 경향을 나타내었 다. 이는 MEA, DEA, TEA가 반응온도에서 발생되는 수산화기의 양 이 적어서 $\mathrm{TiO}_{2}$ 의 생성을 억제했기 때문으로 판단된다. 그리고 Fig. 1(b)에서 볼 수 있듯이 음이온성 계면활성제인 SDBS와 양이온성 계 면활성제인 $\mathrm{CTAB}$ 을 사용한 경우 비이온성 계면활성제인 Span 20 


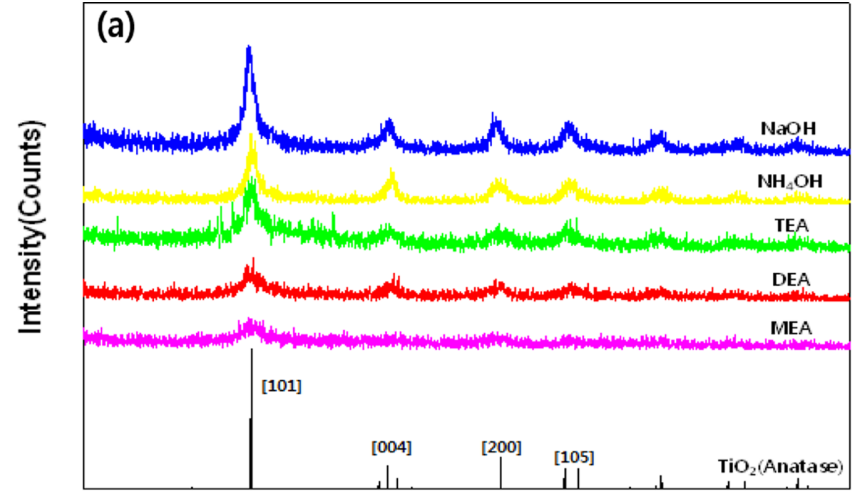

2-Theta (degree)

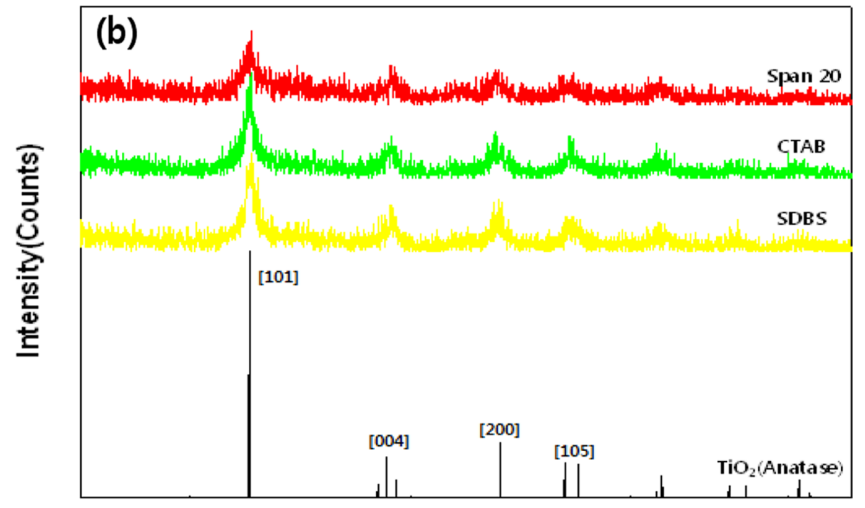

2-Theta (degree)

Fig. 1. XRD patterns of $\mathrm{TiO}_{2}$ particles obtained at different conditions: (a) effect of base solutions (conc. of $\mathrm{Ti}\left(\mathrm{SO}_{4}\right)_{2} \mathrm{O} .5 \mathrm{M}$, temperature 95 and $\mathrm{pH} 11.0$ ), (b) effect of surfactants (conc. of $\mathrm{Ti}\left(\mathrm{SO}_{4}\right)_{2} 0.5 \mathrm{M}$, temperature 95 and $\left.\mathrm{pH} 11.0\right)$.

Table 1. Particle size of $\mathrm{TiO}_{2}$ prepared from different base solutions

\begin{tabular}{cc}
\hline \hline Precipitant $^{\mathrm{a}}$ & Zeta-potential \\
\cline { 2 - 2 } & Particle size $[\mathrm{nm}]$ \\
\hline MEA & 321.6 \\
DEA & 272.7 \\
TEA & 51.3 \\
$\mathrm{NH}_{4} \mathrm{OH}$ & 72.6 \\
$\mathrm{NaOH}$ & 50.0 \\
\hline
\end{tabular}

${ }^{\mathrm{a}}$ conc. of $\mathrm{Ti}\left(\mathrm{SO}_{4}\right)_{2} 0.5 \mathrm{M}$, temperature $95^{\circ} \mathrm{C}, \mathrm{pH} 11.0$.

을 사용한 경우보다 결정성이 우수한 경향을 가지는 것을 확인할 수 있다.

침전제 종류에 따른 입자크기를 Table 1에 나타내었으며, 입자크 기 분석결과를 보면 입자크기가 작을수록 결정성이 큰 경향을 확인 할 수 있다. 이는 입자끼리의 응집으로 인해 입자크기가 점점 커지 고 결정성이 떨어지게 되는 것으로 판단된다. 특히, 침전제로 TEA 를 사용한 경우 $\mathrm{DEA}$ 나 $\mathrm{MEA}$ 를 사용한 경우보다 입자크기가 작은 것을 확인할 수 있는데, 이는 반응온도인 $95{ }^{\circ} \mathrm{C}$ 에서 $\mathrm{MEA}$ 나 $\mathrm{DEA}$ 보 다 TEA가 수산화기를 많이 생성하여 침전제로서 작용하고 수산화 기가 떨어져 나간 잔여분자들이 생성된 $\mathrm{TiO}_{2}$ 입자를 분산시켜 작은 $\mathrm{TiO}_{2}$ 입자가 생성된 것으로 생각된다.

그리고 $\mathrm{Kim}$ 등 [15]은 수열합성 시 침전제로 $\mathrm{NaOH}$ 와 $\mathrm{NH}_{4} \mathrm{OH}$ 를 사용하여 $\mathrm{TiO}_{2}$ 를 합성하였는데, 침전제로 $\mathrm{NaOH}$ 를 사용한 경우보다
Table 2. Particle size of $\mathrm{TiO}_{2}$ prepared with different surfactants

\begin{tabular}{cc}
\hline \hline Surfactant $^{\mathrm{a}}$ & Zeta-potential \\
\cline { 2 - 2 } & Particle size $[\mathrm{nm}]$ \\
\hline CTAB & 10.9 \\
Span 20 & 14.5 \\
SDBS & 22.9
\end{tabular}

${ }^{\mathrm{a}}$ Concentration ratio of $\mathrm{Ti}\left(\mathrm{SO}_{4}\right)_{2}$ : Surfactant $=20: 1, \mathrm{NaOH}$ precipitant, conc. of $\mathrm{Ti}\left(\mathrm{SO}_{4}\right)_{2} 0.5 \mathrm{M}$, temperature $95^{\circ} \mathrm{C}$ and $\mathrm{pH}$ 11.0.

$\mathrm{NH}_{4} \mathrm{OH}$ 를 사용한 경우가 결정성이 더 우수하고 응집이 작은 $\mathrm{TiO}_{2}$ 입자의 형성에 유리하다고 보고하였다. $\mathrm{Kim}$ 등 [15]의 연구와 달리 본 연구에서는 소성과정없이 한 단계의 수열합성법으로 $\mathrm{TiO}_{2}$ 를 생 성했기 때문에 침전제로 수산화기 생성량이 작은 $\mathrm{NH}_{4} \mathrm{OH}$ 를 사용하 는 경우보다 수산화기 생성량이 많은 $\mathrm{NaOH}$ 를 사용한 경우가 더 결 정성이 우수하고 응집이 더 적게 발생하고, 이로 인해 크기가 작은 $\mathrm{TiO}_{2}$ 입자를 제조하기 용이한 것으로 판단된다.

Table 2에서 나타낸 바와 같이 SDBS, Span 20, CTAB 순으로 입 자크기가 작아지는 것을 확인할 수 있는데, $\mathrm{TiO}_{2}$ 입자의 표면전하가 양전하를 띄고 있어 음이온성 계면활성제인 SDBS나 비이온성 계면 활성제인 Span 20보다 양이온성 계면활성제인 $\mathrm{CTAB}$ 이 $\mathrm{TiO}_{2}$ 입자 와 미셀을 형성할 때 미셀끼리 또는 미셀과 $\mathrm{TiO}_{2}$ 입자 사이의 반발 력이 가장 크기 때문에 응집으로 인한 입자크기 증가를 최소화시켰 기 때문으로 판단된다.

그리고 동일한 제조조건에서 계면활성제를 첨가한 경우와 첨가하 지 않은 경우를 비교해 보면 계면활성제를 첨가하지 않은 경우 입자 크기가 $50 \mathrm{~nm}$ 에서 계면활성제 $\mathrm{CTAB}$ 을 첨가함에 따라 약 $1 / 5$ 의 크 기인 $10.9 \mathrm{~nm}$ 까지 입자크기가 감소하는 것을 확인할 수 있다.

Fig. 2는 침전제로 $\mathrm{NaOH}$ 를 사용하고 첨가되는 계면활성제 종류 를 달리하여 제조한 나노크기 $\mathrm{TiO}_{2}$ 입자의 $\mathrm{SEM}$ 분석결과를 나타 낸 것으로 계면활성제의 종류에 무관하게 제조된 $\mathrm{TiO}_{2}$ 입자의 형상 은 불규칙상으로 보여진다. Liao와 Liao [10]의 연구에서는 $\mathrm{TiO}_{2}$ 제 조 시 첨가하는 계면활성제의 종류에 따라 막대형상, 타원형상 등 으로 조절가능하다고 보고하였다. 하지만 사용되는 계면활성제의 종류가 다르고 한 단계로 $\mathrm{TiO}_{2}$ 를 제조하는 수열합성법으로 나노크 기 $\mathrm{TiO}_{2}$ 입자를 제조한 본 연구의 경우에는 이러한 현상을 관찰할 수 없었다.

3-1-2. 계면활성제 CTAB 첨가 시 제조조건이 $\mathrm{TiO}_{2}$ 입자크기에 미 치는 영향

$0.5 \mathrm{M} \mathrm{Ti}\left(\mathrm{SO}_{4}\right)_{2}$ 수용액에 양이온성 계면활성제인 $\mathrm{CTAB}$ 를 일정농도 첨가하고 침전제로 $\mathrm{NaOH}$ 를 사용하여 한 단계의 수열합성법을 통해 나노입자 $\mathrm{TiO}_{2}$ 분말을 제조하는 과정 중 제조조건들에 따라 제조된 시료들의 입자크기 분석결과를 Fig. 3 5에 나타내었다.

Fig. 4 와 Fig. 5 를 보면 $\mathrm{CTAB}$ 첨가 시 혼합용액의 $\mathrm{pH}$ 나 반응온도 는 제조된 $\mathrm{TiO}_{2}$ 입자의 입자크기에 큰 영향을 미치지 않는 것을 확 인할 수 있다. 반면 Fig. 3에서 볼 수 있듯이 첨가하는 CTAB의 농도 는 제조된 $\mathrm{TiO}_{2}$ 입자의 입자크기에 큰 영향을 미치는 것을 확인할 수 있다. $0.05 \mathrm{M} \mathrm{CTAB}$ 을 첨가하는 경우, 즉 전구체인 $\mathrm{Ti}\left(\mathrm{SO}_{4}\right)_{2}$ 수용액과 $\mathrm{CTAB}$ 의 농도비가 $10: 1$ 일 때 $5.8 \mathrm{~nm}$ 로 가장 작은 입자크기의 $\mathrm{TiO}_{2}$ 입자가 생성되는 것을 확인할 수 있다. 이는 $\mathrm{Ti}\left(\mathrm{SO}_{4}\right)_{2}$ 수용액과 $\mathrm{CTAB}$ 의 농도비가 $10: 1$ 일 때까지는 분산효과가 증가하지만 $\mathrm{CTAB}$ 

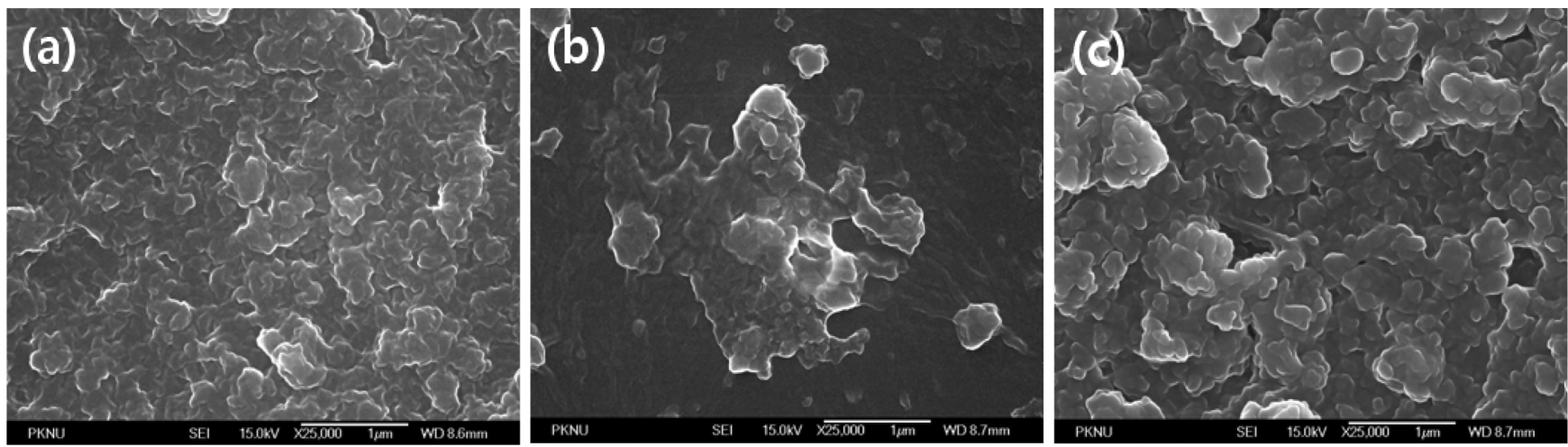

Fig. 2. SEM images of $\mathrm{TiO}_{2}$ particles prepared from $\mathrm{NaOH}$ at temperature $95{ }^{\circ} \mathrm{C}$, concentration ratio of $\mathrm{Ti}\left(\mathrm{SO}_{4}\right)_{2}$ : $\mathrm{Surfactant}=20: 1$, concentration of $\mathrm{Ti}\left(\mathrm{SO}_{4}\right)_{2} 0.5 \mathrm{M}$ and $\mathrm{pH}$ 11.0: (a) CTAB, (b) Span 20, (c) SDBS.

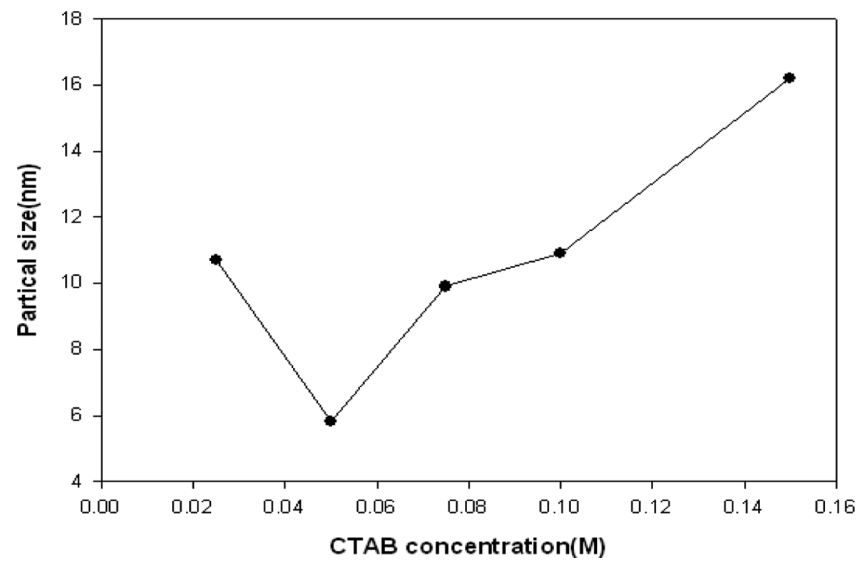

Fig. 3. The effect of concentration of CTAB on the particle size of nanosized $\mathrm{TiO}_{2}$ (conc. of $\mathrm{Ti}\left(\mathrm{SO}_{4}\right)_{2} \mathrm{O.5} \mathrm{M}, \mathrm{pH}$ 11.0, temperature $95^{\circ} \mathrm{C}$ and $\mathrm{NaOH}$ precipitant).

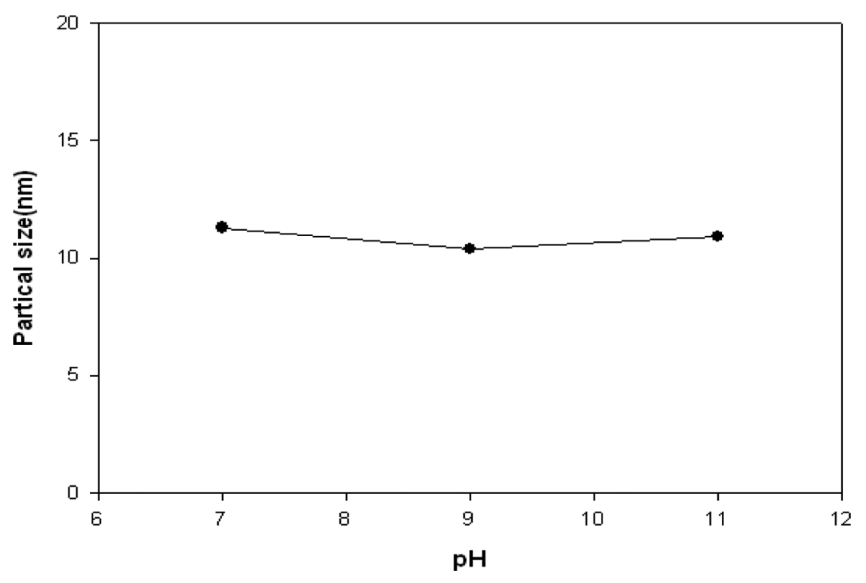

Fig. 4. The effect of $\mathrm{pH}$ on the particle size of nanosized $\mathrm{TiO}_{2}$ (conc. of $\mathrm{Ti}\left(\mathrm{SO}_{4}\right)_{2} \mathrm{O} .5 \mathrm{M}$, conc. of CTAB $0.1 \mathrm{M}$, temperature $95{ }^{\circ} \mathrm{C}$ and $\mathrm{NaOH}$ precipitant).

의 농도가 증가할수록 정전기적 인력에 의해 미셀에 붙는 $\mathrm{CTAB}$ 의 양이 많아지고, 그로 인해 $\mathrm{TiO}_{2}$ 가 미셀에 붙으면서 입자크기가 점점 증가되는 것으로 생각된다. 그리고 동일한 조건에서 최적의 전구체 와의 농도비로 $\mathrm{CTAB}$ 을 첨가한 경우와 첨가하지 않은 경우의 제 조된 $\mathrm{TiO}_{2}$ 입자크기를 비교하면 첨가하지 않은 경우 $50 \mathrm{~nm}$ 의 $\mathrm{TiO}_{2}$ 입자가 생성되지만 최적의 전구체와의 농도비로 $\mathrm{CTAB}$ 을 첨가한

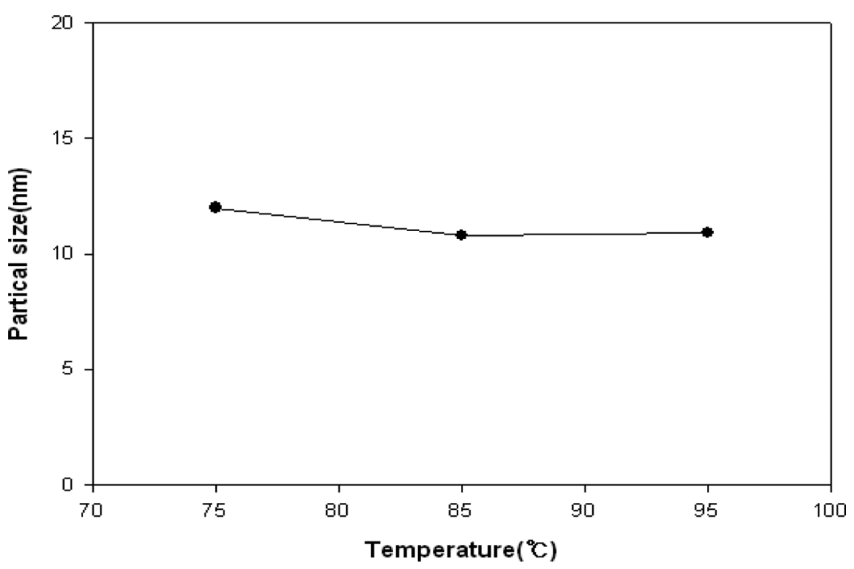

Fig. 5. The effect of temperature on the particle size of nanosized $\mathrm{TiO}_{2}$ (conc. of $\mathrm{Ti}\left(\mathrm{SO}_{4}\right)_{2} \mathrm{O.5} \mathrm{M}$, conc. of CTAB $0.1 \mathrm{M}, \mathrm{pH} 11.0$ and $\mathrm{NaOH}$ precipitant).

경우 $5.8 \mathrm{~nm}$ 로 약 $1 / 10$ 정도 입자크기가 감소하는 것을 확인할 수 있다.

\section{3-2. $\mathrm{TiO}_{2}$ 입자의 광학 특성}

3-2-1. 침전제와 계면활성제 종류가 광학 특성에 미치는 영향

제조된 시료들의 흡광면적을 이용하여 광촉매 활성을 비교하였다. Fig. 6과 Fig. 7은 침전제 종류와 계면활성제의 종류에 따라 제조된 $\mathrm{TiO}_{2}$ 입자의 DRS 분석결과를 나타내었으며, 제조된 $\mathrm{TiO}_{2}$ 입자들은 모두 자외선 영역인 400 $200 \mathrm{~nm}$ 의 파장범위에서 활성을 띄는 것을 확인할 수 있다.

그리고 침전제 종류와 계면활성제 종류에 따라 제조된 나노크기 $\mathrm{TiO}_{2}$ 입자의 흡광면적은 Table 1과 Table 2에서 나타낸 입자크기 분 석결과에서 알 수 있는 바와 같이 Fig. 6과 Fig.7에서 입자크기가 작 을수록 흡광면적이 커지는 경향을 확인할 수 있다. 입자크기가 감소 할수록 비표면적이 증가하게 되고, 그로 인해 흡광면적이 증가하게 되는 것으로 판단된다.

3-2-2. 계면활성제 $\mathrm{CTAB}$ 의 농도, $\mathrm{pH}$, 반응온도에 따른 광학 특성 Fig. 8 10은 $\mathrm{CTAB}$ 첨가 시 첨가농도와 $\mathrm{pH}$ 및 온도 변화에 따라 제조된 $\mathrm{TiO}_{2}$ 입자들의 흡광면적을 나타내었다.

Fig. 8 10에서 볼 수 있듯이 CTAB 첨가 시 제조조건에 따라 제조 


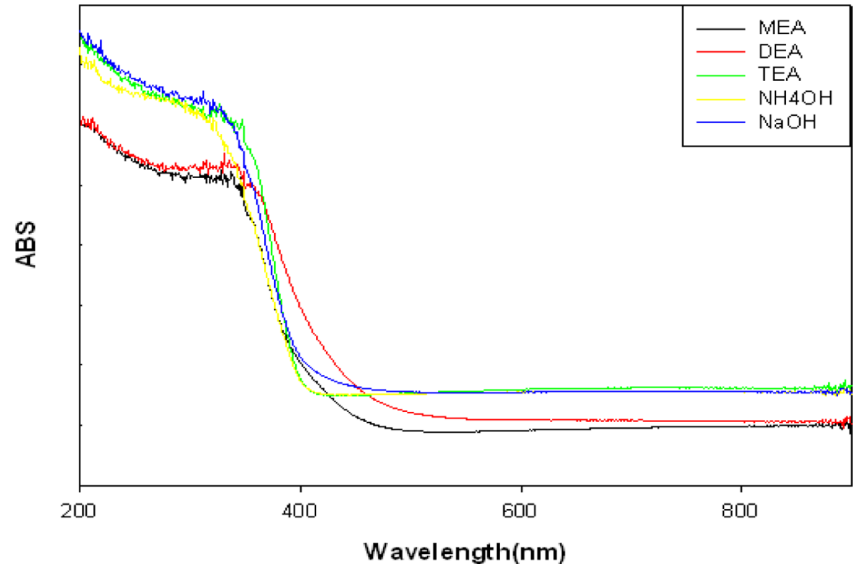

Fig. 6. DRS spectrum of the nanosized $\mathrm{TiO}_{2}$ particles prepared from different base solutions (conc. of $\mathrm{Ti}\left(\mathrm{SO}_{4}\right)_{2} \mathrm{O} .5 \mathrm{M}$, temperature $95^{\circ} \mathrm{C}$ and $\mathrm{pH}$ 11.0).

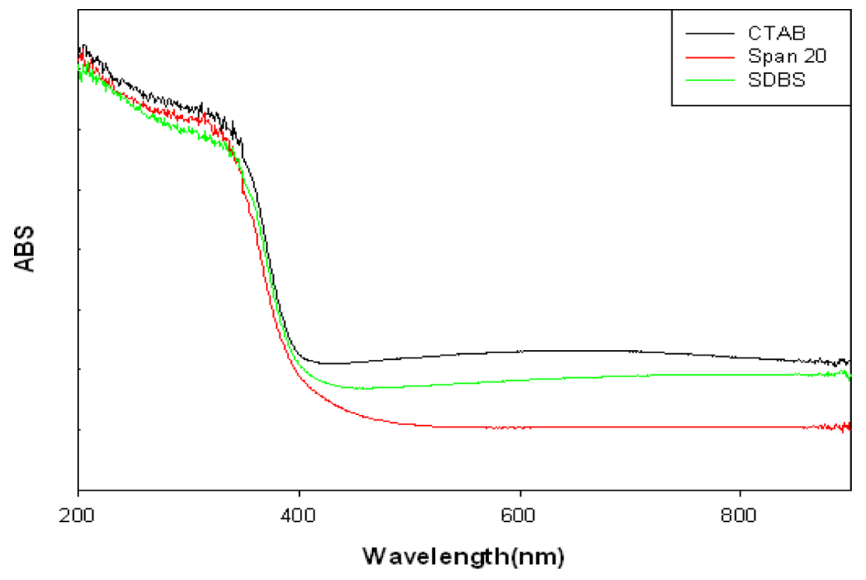

Fig. 7. DRS spectrum of the nanosized $\mathrm{TiO}_{2}$ particles prepared with different surfactants $\left(\mathrm{NaOH}\right.$ precipitant, conc. of $\mathrm{Ti}\left(\mathrm{SO}_{4}\right)_{2}$ $0.5 \mathrm{M}$, temperature $95^{\circ} \mathrm{C}$ and $\mathrm{pH} 11.0$ ).

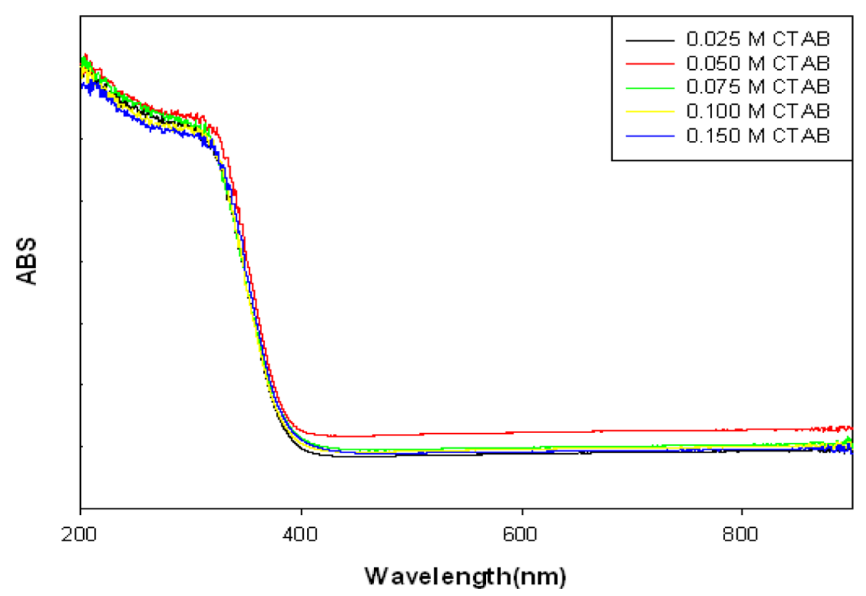

Fig. 8. DRS spectrum of the nanosized $\mathrm{TiO}_{2}$ particles prepared at different concentrations of CTAB (conc. of $\mathrm{Ti}\left(\mathrm{SO}_{4}\right)_{2} \mathrm{O.5} \mathrm{M}$, temperature $95{ }^{\circ} \mathrm{C}, \mathrm{pH} 11.0$ and $\mathrm{NaOH}$ precipitant).

된 $\mathrm{TiO}_{2}$ 입자의 흡광면적도 3-2-1에서 고찰되었듯이 제조된 $\mathrm{TiO}_{2}$ 입 자크기가 작을수록 비표면적이 증가하고 그로 인해 빛을 흡수하는 흡광면적이 증가하는 것을 확인할 수 있다.

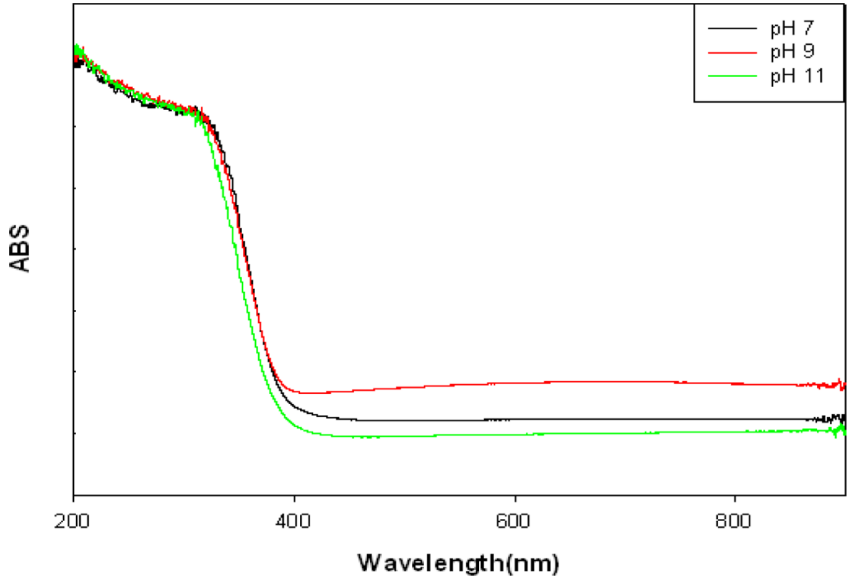

Fig. 9. DRS spectrum of the nanosized $\mathrm{TiO}_{2}$ particles prepared at different $\mathrm{pH} 9$ (conc. of $\mathrm{Ti}\left(\mathrm{SO}_{4}\right)_{2} 0.5 \mathrm{M}$, conc. of CTAB $0.1 \mathrm{M}$, temperature $95^{\circ} \mathrm{C}$ and $\mathrm{NaOH}$ precipitant).

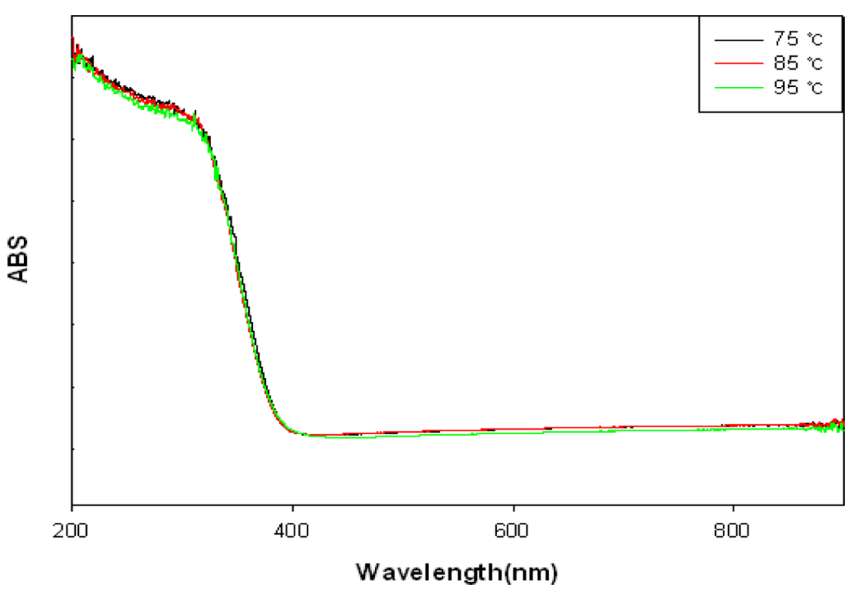

Fig. 10. DRS spectrum of the nanosized $\mathrm{TiO}_{2}$ particles prepared at different temperature (conc. of $\mathrm{Ti}\left(\mathrm{SO}_{4}\right)_{2} \mathrm{O} .5 \mathrm{M}$, conc. of CTAB $0.1 \mathrm{M}, \mathrm{pH} 11.0$ and $\mathrm{NaOH}$ precipitant).

\section{4. 결 론}

(1) $95^{\circ} \mathrm{C}$ 와 상압에서 고온의 열처리과정을 거치지 않는 한 단계 의 수열합성법을 통해 순수한 anatase 결정구조를 갖는 나노크기의 $\mathrm{TiO}_{2}$ 입자를 제조할 수 있었다.

(2) 침전제로 사용하는 염기성 용액 중 $\mathrm{NaOH}$ 가 결정성이 우수하 고 작은 크기의 $\mathrm{TiO}_{2}$ 입자를 제조하는데 적합함을 알 수 있었다.

(3) 수열합성 시 계면활성제를 이용하여 $\mathrm{TiO}_{2}$ 의 입자크기를 조절하 는 방법으로 광촉매 활성을 증가시킬 수 있었고, 양이온성 계면활성 제인 $\mathrm{CTAB}$ 를 첨가할 때 가장 작은 크기의 $\mathrm{TiO}_{2}$ 를 제조할 수 있었다.

(4) 전구체인 $\mathrm{Ti}\left(\mathrm{SO}_{4}\right)_{2}$ 수용액과 $\mathrm{CTAB}$ 의 최적의 농도비는 $10: 1$ 임을 확인하였고, 계면활성제를 첨가하지 않은 경우보다 적절한 농 도의 $\mathrm{CTAB}$ 를 첨가하여 제조할 경우 $\mathrm{TiO}_{2}$ 의 입자크기가 $1 / 10$ 로 감 소하였다.

\section{감 사}

이 논문은 부경대학교 자율창의학술연구비(2013년 : 과제번호 CD-2013-0568)에 의하여 연구되었습니다. 


\section{References}

1. Peng, T., Zhao, D., Dai, K., Shi, W. and Hirao, K., "Synthesis of Titanium Dioxide Nanoparticles with Mesoporous Anatase Wall and High Photocatalytic Activity,' J. Phys. Chem. B, 109, 49474952(2005).

2. Wang, F., Shi, Z., Gong, F., Jiu, J. and Adachi, M., "Morphology Control of Anatase $\mathrm{TiO}_{2}$ by Surfactant-assisted Hydrothermal Method,' Chin. J. Chem. Eng., 15(5), 754-759(2007).

3. Cheng, H., Ma, J., Zhao, Z. and Qi, L., "Hydrothermal Preparation of Uniform Nanosize Rutile and Anatase Particle,' Chem. Mater., 7, 663-671(1995).

4. Lee, B. M., Shin, D. Y. and Han, S. M., "Synthesis of Hydrous $\mathrm{TiO}_{2}$ Powder by Dropping Precipitant Method and Photocatalytic Properties,' J. Korean Ceramic Soci., 37(4), 308-313(2000).

5. Seo, D. S., Lee, J. K., You, H. G. and Kim, H., "Preparation of $\mathrm{TiO}_{2}$ Nanocrystalline Powder at Low Temperature,' Korean J. Ceramic Soci., 38(4), 331-336(2001).

6. Chen, K., Li, J., Wang, W., Zhang, Y., Wang, X. and Su, H., "Effect of Surfactants on Microstructure and Photocatalytic Activity of $\mathrm{TiO}_{2}$ Nanoparticles Prepared by the Hydrothermal Method," Mater. Sci. Semicond. Process, 15, 20-28(2012).

7. Jung, M. W. and Kwak, Y. J., "Synthesis and Photoactivity of $\mathrm{SnO}_{2}$-Doped Anatase-Type $\mathrm{TiO}_{2}$ Powder via Polymerization-Complex Route,' J. Korean Ind. Eng. Chem., 17(5), 561-564(2006).

8. Wang, H., Liu, P., Cheng, X., Shui, A. and Zeng, L., "Effect of
Surfactant on Synthesis of $\mathrm{TiO}_{2}$ Nano-particles by Homogeneous Precipitation Method,' Powder Technol., 188, 52-54(2008).

9. Lee, M. S., Ju, C. S., Lee, G. D. and Hong, S. S., "Effect of the Water/ Surfactant Molar Ratio $\left(\mathrm{W}_{0}\right)$ on Synthesis of Nanosized $\mathrm{TiO}_{2} / \mathrm{SiO}_{2}$ by W/O Microemulsion and Their Photocatalytic Activity, Korean Chem. Eng. Res. (HWAHAK KONGHAK), 41(4), 432-438(2003).

10. Liao, D. L. and Liao, B. Q., "Shape, Size and Photocatalytic Activity Control of $\mathrm{TiO}_{2}$ Nanoparticles with Surfactants,' J. Photochem. Photobiol. A-Chem., 187, 363-369(2007).

11. Hidalgo, M. C., Aguilar, M., Maicu, M., Navio, J. A. and Colon, G., "Hydrothermal Preparation of Highly Photoactive $\mathrm{TiO}_{2}$ Nanopartuicles,' Catal. Today, 129, 50-58(2007).

12. Na, S. E., Jeong, S. G., Jeong, G. S., Kim, S. Y. and Ju, C. S., "Preparation of Zinc Oxide by Hydrothermal Precipitaation and Degradation of Tartrazine,' Korean Chem. Eng. Res.(HWAHAK KONGHAK), 49(6), 752-757(2011).

13. Woo, S. H. and Kim, W. W., "Scale up Test of Ultrafine $\mathrm{TiO}_{2}$ Powder by Homogeneous Precipitation Process at Low Temperatures,' Trends in Metals \& Mat. Eng., 19(3), 8-12(2006).

14. Kim, S. Y., "Preparation, Characterization and Photocatalytic Activities of Titanium Dioxide Nanoparticles', Master degree, Department of Chemical Engineering, Chungbuk National University, Cheongju, Korea(2010).

15. Kim, G. H., Lee, W. J., Kim, D. G., Lee, S. K., Lee, S. H. and Kim, I. S., "Synthesis of Nano-sized $\mathrm{TiO}_{2}$ Powder Using a Hydrothermal Process,' Korean J. Met. Mater, 48(6), 543-550(2010). 